\title{
Development of standard operating procedures, phytochemical screening with HPTLC fingerprint of a polyherbal formulation
}

\author{
Aaisha Ansari, Mohammed Abdul Rasheed Naikodi*, Uzma Viquar», Javed Inam Siddiqui*, Munawwar Husain Kazmi \\ P.G. Department of Pharmacology, National Research Institute of Unani Medicine for Skin Disorders, A.G. Colony Road, Erragadda, \\ Hyderabad-500038, Telangana State, India \\ *Drug standardization Research Unit and P.G. Department of Pharmacology, National Research Institute of Unani Medicine for Skin \\ Disorders, A.G. Colony Road, Erragadda, Hyderabad-500038, Telangana State, India
}

\section{Article Info}

Article history

Received 7 September 2020

Revised 28 October 2020

Accepted 30 October 2020

Published online 30 December 2020

\section{Keywords}

HPTLC

Phytochemical

Quality standard

Standardization

\begin{abstract}
Unani Medicines have been in use from centuries, but have not been able to achieve its importance globally in spite of their efficacy. This is mainly due to the fact that there is a lack of standard operating procedures (SOPs) of the manufacturing steps and establishment of monographs of standardization parameters which create difficulties in establishing the quality of drug. The essential role for the development of SOPs and physiochemical standardization studies is to improve the quality of medicines. Likewise, there are a large number of drugs in the Unani System of Medicine which have proved to be much effective and safer than the Modern Medicine. The safety and efficacy of such drugs depend on the identity, purity and strength of the ingredient used in the formulation. Hence, SOPs becomes an essential part of preparation of formulation and motivated to study Itrifal Hakeem Ali (IHA) a Unani formulation for its standardization process and to develop SOPs. IHA, mentioned in the classical Unani Pharmacopoeias prepared in three batches, following the general method of preparation of Itrifal as described in Unani Pharmacopeia of India (UPI). IHA is quoted as quite effective in the classical Unani texts for skin depigmentation disorders, specifically for vitiligo, pityriasis and naevi. The standardization parameters as per UPI for organoleptic evaluation, physicochemical properties and safety studies, viz., microbial load, aflatoxin, heavy metal and pesticide residue contamination was studied. HPTLC fingerprint studies of IHA was developed and phytochemical screening carried out qualitative in alcohol, chloroform and aqueous extract of IHA to identify the nature of phytoconstituents present in the formulation.
\end{abstract}

\section{Introduction}

Medicines from natural sources are being used in various traditional systems of medicine worldwide since antiquated occasions and still are utilized for the treatment of different diseases. The mankind relies for healing of diseases through nature. A large section of the population, particularly in developed and under developing countries, relies on the time-tested traditional/alternative medicines such as Unani, Ayurveda, etc., many of which are far older than allopathic medical knowledge. In spite of so many successes and recent advances, modern medicine finds it difficult to reach out to everyone and deal with chronic diseases (Sen and Chakraborty, 2017). It is a time tested fact that the medicines produced from plant sources are more effective and safe (Kamboj, 2000) against many diseases. Furthermore, the people from low socio-economic status cannot afford to modern medicines due to higher cost whereas

Corresponding author: Dr. Uzma Viquar

Associate Professor, P.G. Department of Pharmacology, National Research Institute of Unani Medicine for Skin Disorders, A.G. Colony Road, Erragadda, Hyderabad-500038, Telangana, India

E-mail: viquar.uzma@gmail.com

Tel.: +91-9885101648

Copyright (c) 2020 Ukaaz Publications. All rights reserved.

Email: ukaaz@yahoo.com; Website: www.ukaazpublications.com the plant based medicines are a boon for them (Kamboj, 2000; WHO, 2014). In addition to these, herbal drugs are known to have lesser side effects than the synthetic medicines (WHO, 2014). Although, the belief of drug being used from natural sources to be free from all kinds of side effects, is not necessarily true (Aneesh et al., 2009; Ekor, 2013; WHO, 2014) due to commercialization, adulteration and substitution of the drugs (Aneesh et al., 2009). Therefore, the quality assurance of the drug becomes an essential criteria. The majority of population in India relies on Unani, Ayurveda, Yoga and Naturopathy, Siddha and Homeopathy (AYUSH) systems of medicine for the treatment of various diseases. Within the realm of the Unani System of Medicine, since centuries there are a large number of effective single drugs and compound formulations are being used, still they are lagging due to lack of standardization and low quality during manufacturing. So far, many formulations have not been studied with scientific validations as well as for their quality control methods, using modern analytical techniques. Hence, it is necessary to come up with a systematic approach to develop well designed methodologies for the standardization of the Unani formulations and produce authentic and good quality products through Good Manufacturing Practices (GMP) to laid standard operating procedures (SOPs). 
Standardization serves the purpose of asserting quality, purity, and efficacy of the produce and ensuring batch-to-batch consistency of finished products (Hariharan and Subburaju, 2012; Kumari and Kotecha, 2016). In conventional medicines, the adverse medicinal effects and lack of medicines for some diseases have led to the reemergence of traditional medicines, with possible solutions to many health issues and, thus the use of these medicines has increased worldwide. WHO, specific in developing countries, encourages to utilize plant derived medicine even though the rationale is to reduce the economic burden and easily available to everyone. WHO emphasizes on the significance of qualitative and quantitative approaches for standardization of herbal drugs and has formulated analytical standards for herbal drugs (Anonymous, 2007c; Parthik et al., 2011; WHO, 2011). According to WHO, all drugs should meet specific requirements of being safe and effective (Parthik et al., 2011). WHO has generated numerous documents as Good Agriculture and Collection Practices (GACP), Good Manufacturing Practices (GMP), quality control of herbal medicines (Anonymous, 2007c; Parthik et al., 2011; WHO, 2015 and 2018).

Many effective single drugs and compound formulations are mentioned in Unani literature for the treatment of skin depigmentation disorders. There is a need for developing quality standards for such drugs, thereby ensuring their efficacy, safety, and potency in such skin depigmentary disorders. In the classical Unani literature, the polyherbal formulation, Itrifal Hakeem Ali (IHA) reported effective in vitiligo, pityriasis and naevi (Khan, 2005; Khan, 2009). The polyherbal formulation IHA was composed of nine ingredients, viz., Aamla (Phyllanthus emblica L.), Aftimoon (Cuscuta reflexa Roxb.), Aqarqarha (Anacyclus pyrethrum (L.) Lag.), Balela (Terminalia bellirica (Gaertn.) Roxb.), Filfil Daraz (Piper longum L.), Halela-kabuli (Terminalia chebula Retz.), Shitraj Hindi (Plumbago zeylanica L.), Taj (Cinnamomum cassia (L.) J.Presl) and Asl (honey). Till now, as there were no reports found in respect of standardization of IHA, hence, IHA was selected to carry out the detailed study. The development of standard operating procedures and standardization are of great importance to ensure the quality and authenticity of the herbal drug. The determination of physicochemical parameters for the authenticity of the drug is necessary before studying for its pharmacological activity. The quality control parameters for the standardization of IHA included organoleptic evaluation, microscopic examination, physicochemical analysis, phytochemical analysis, high performance thin layer chromatography (HPTLC) and safety evaluation parameters, viz., microbial load, aflatoxins, heavy metal and pesticides residual analysis.

\section{Materials and Methods}

2.1 Procurement and authentication of ingredients of the formulation

The ingredients of IHA were procured from pharmacy (GMP certified), NRIUMSD and drug dealers from local market of Hyderabad, Telangana. The herbal drug, eight raw ingredients were identified and authenticated by the Botanist, Survey of Medicinal Plants Unit (SMPU), NRIUMSD, Hyderabad, vide authentication/ voucher specimen numbers as: i. SMPU/CRI-Hyd 14090 (Phyllanthus emblica L.), ii. SMPU/CRI-Hyd14091 (Cuscuta reflexa Roxb.), iii. SMPU/CRI-Hyd14092 (Anacyclus pyrethrum (L.) Lag.), iv. SMPU/CRI-Hyd14093 (Terminalia bellirica (Gaertn.) Roxb.), v. SMPU/CRI-Hyd14094 (Piper longum L.), vi. SMPU/ CRI-Hyd14095 (Terminalia chebula Retz.), vii. SMPU/CRIHyd14096 (Plumbago zeylanica L.) and viii. SMPU/CRI-Hyd14097 (Cinnamomum cassia (L.) J.Presl). Three batches of the formulation was prepared in the Pharmacy, NRIUMSD, Hyderabad, using the composition of IHA (Table 1, Figure 1) as mentioned in the classical Unani Pharmacopoeia; Qarabadeen Azam-o-Akmal, Qarabadeen Azam (Khan, 2005; Khan, 2009) and general method for the preparation of the Itrifal mentioned in the National Formulary of Unani Medicine (NFUM) and Unani Pharmacopoeia of India (UPI) (Anonymous, 2007a, 2007b).

Table 1: Composition of IHA

\begin{tabular}{|l|l|l|l|l|}
\hline S.No. & Ingredients & Botanical name & Part used & Quantity \\
\hline 1 & Post halela-kabuli & Terminalia chebula Retz. & Pericarp of matured dried fruit & $17.5 \mathrm{~g}$ \\
2 & Post balela & Terminalia bellirica (Gaertn.) Roxb. & Pericarp of matured dried fruit & $17.5 \mathrm{~g}$ \\
3 & Aamla & Phyllanthus emblica L. & Pericarp of matured dried fruit & $17.5 \mathrm{~g}$ \\
4 & Aftimoon & Cuscuta reflexa Roxb. & Whole plant & $17.5 \mathrm{~g}$ \\
5 & Aqarqarha & Anacyclus pyrethrum (L.) Lag. & Root & $7.0 \mathrm{~g}$ \\
6 & Shitraj hindi & Plumbago zeylanica Linn. & Root & $7.0 \mathrm{~g}$ \\
7 & Filfil daraz & Piper longum Linn. & Dried fruit & $14.0 \mathrm{~g}$ \\
8 & Taj & Cinnamomum cassia Blume. & Dried stem bark & $14.0 \mathrm{~g}$ \\
9 & Asl & Honey & -- & $336.0 \mathrm{~g}$ \\
& & & $(3$ times to the weight of all powdered drug) \\
\hline
\end{tabular}

\subsection{Method of preparation}

Ingredients of the pharmacopeial quality were taken, cleaned thoroughly and processed separately to obtain a fine powder. Taj, Aqarqarha and Shitraj hindi were gently crushed and powdered separately. The powdered ingredients are sieved separately using sieve no. 80 to obtain a homogenous powder. Powdered post halela, post balela and Aamla are taken in a flattened dish and rubbed with pure ghee to mix known as crisped. Honey was purified over low flame to remove beeswax and small bits of honeycomb as foreign matter which float on surface. The honey thus obtained was called purified honey. Honey was kept on low fire until the necessary consistency of syrup having 3 strings consistency was achieved. 
To this very carefully add all the powdered drugs and mixed thoroughly to get IHA. The obtained formulation was poured under aseptic conditions in air tight glass containers stored at room temperature, protected from sunlight and moisture. Each step was followed with utmost care to avoid any contamination during preparation of the formulation.

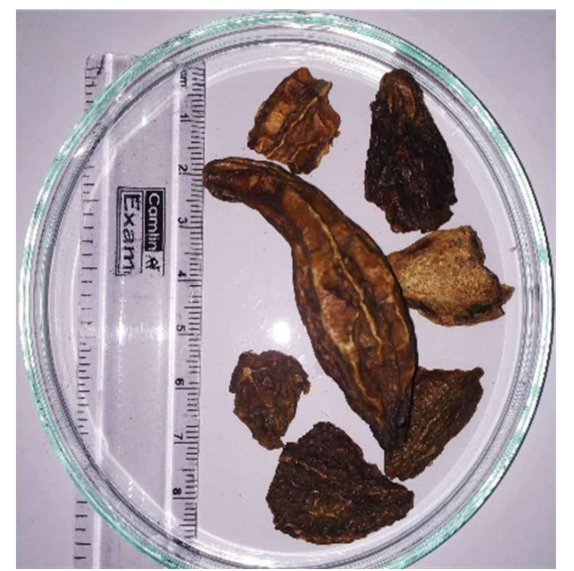

Terminalia chebula Retz. (Halela-Kabuli)

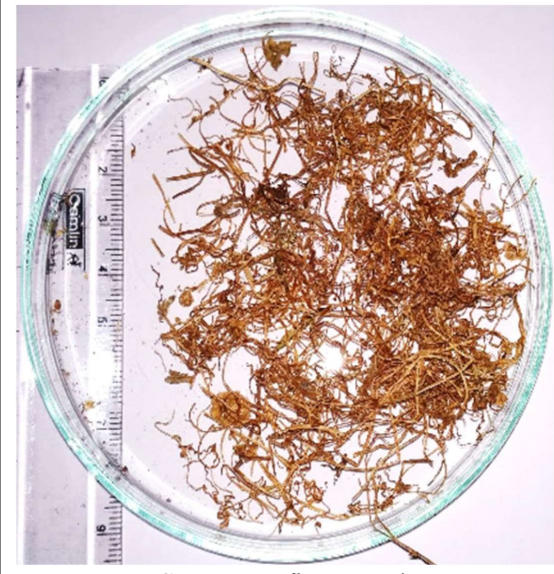

Cuscuta reflexa Roxb.

(Aftimoon)

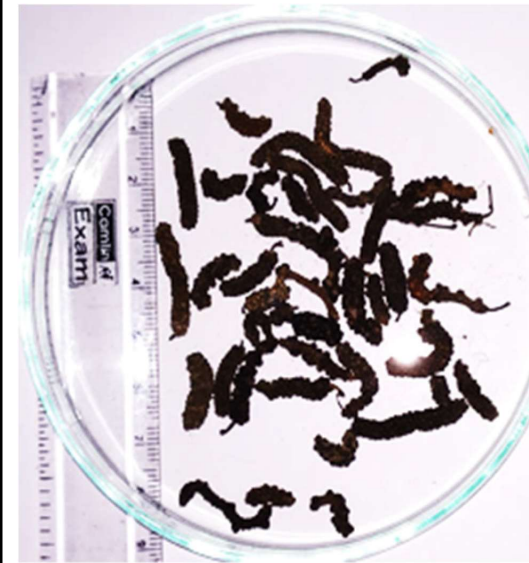

Piper longum Linn.

(Filfil daraz)

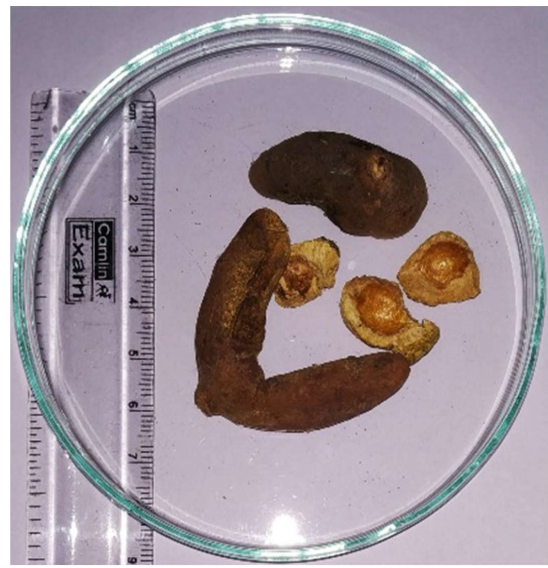

Terminalia bellirica (Gaertn.) Roxb. (Balela)

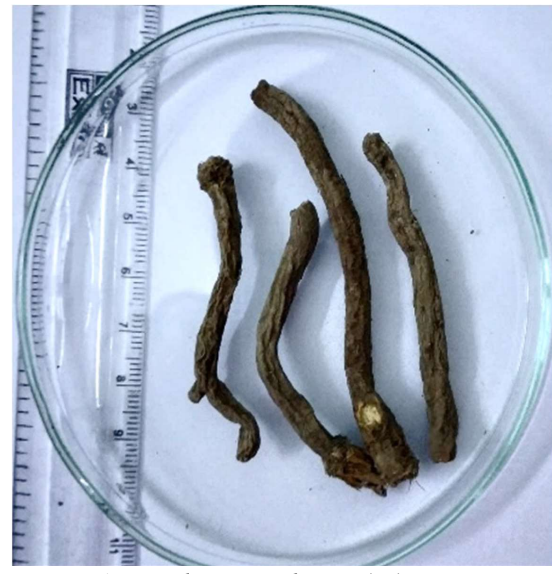

Anacyclus pyrethrum (L.) Lag.

(Aqarqarha)

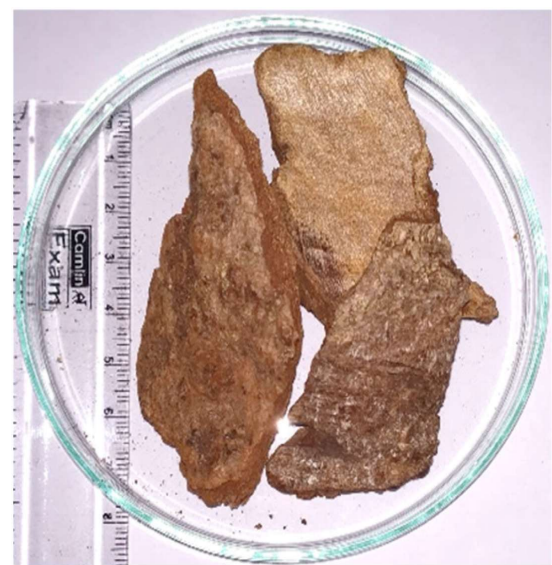

Cinnamomum cassia Blume.

(Taj)

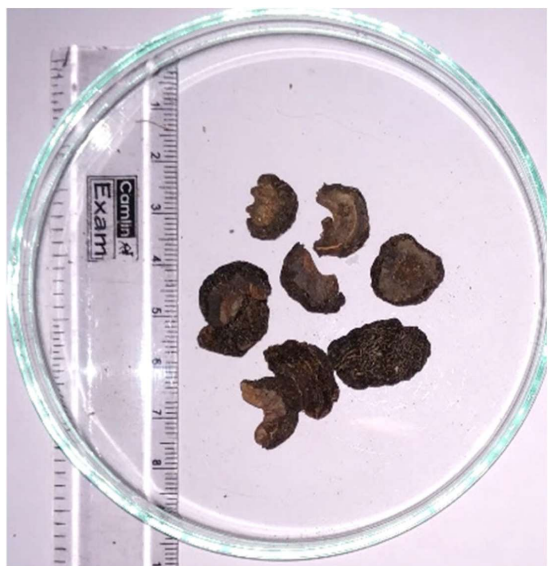

Phyllanthus emblica L. (Aamla)

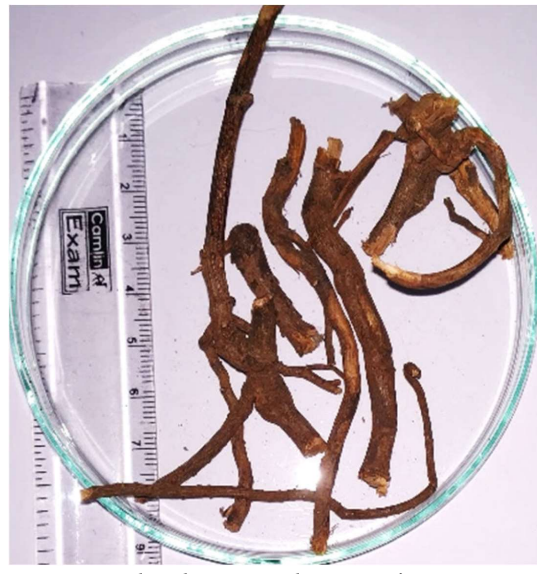

Plumbago zeylanica Linn.

(Shitraj Hindi)

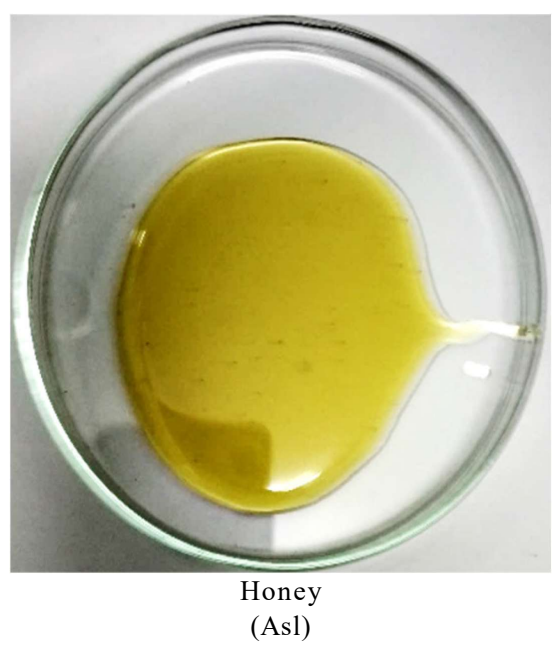

Figure 1: Ingredient of IHA. 


\subsection{Organoleptic characters}

Characters of polyherbal formulation IHA for macroscopic properties such as appearance, colour, odour, taste, etc., were observed through naked eye, sensory organs and are noted.

\subsubsection{Microscopic examination}

Microscopic examination (Anonymous, 2010) of IHA: $5 \mathrm{~g}$ of the sample of IHA was taken and mixed with $50 \mathrm{ml}$ of water in a beaker, with gentle warming, till the sample got completely dispersed in water. Centrifuged the mixture and decanted supernatant. Took a few milligram of the sediment and mounted in glycerine in a watch glass added a few drops of phloroglucinol and concentrated hydrochloric acid, mounted in glycerine to locate lignified cells. Observed in the microscope for various characters in different mounts and recorded.

\subsection{Physicochemical studies}

Physicochemical parameter of IHA such as loss of weight on drying at $105^{\circ} \mathrm{C}, \mathrm{pH}$ of aqueous suspension, alcohol and water soluble matter, ash values: total ash and acid insoluble ash, bulk density, reducing and non-reducing sugars were analysed by standard methods (Anonymous, 2005, 2010; Rasheed et al., 2010; WHO, 2011; Zafar et al., 2020). Detection of microbial load, aflatoxins, analysis of heavy metals and pesticides residue were carried out as per standard methods.

\subsubsection{Loss in weight on drying at $105^{\circ} \mathrm{C}$}

5 gm of IHA was taken in a petri dish and kept in hot air oven for drying at $105^{\circ} \mathrm{C}$ for $5 \mathrm{~h}$. It was allowed to cool and then weighed. The process was continued up to the achievement of a constant value of two consecutive weight. The percentage loss in weight on drying was calculated with reference to the original drug weight.

2.4.2 Determination of ash values (Anonymous, 2005, 2010)

Total ash: in accurately weighed and dried silica crucibles, $5 \mathrm{~g}$ of sample of IHA from each batch was incinerated at $450^{\circ} \mathrm{C}$ in the muffle furnace until it became free from carbon. The crucibles were then allowed to cool and weighed. The percentage of total ash was calculated with reference to the air dried drug. Acid insoluble ash: $25 \mathrm{ml}$ of dilute hydrochloric acid was added into the crucibles containing total ash and was boiled and then filtered through an ash-less filter paper (Whatman 41) and was washed with hot water until the filtrate became neutral. The filter paper containing insoluble matter was transferred to the original crucible, was first dried on a hot-plate and then ignited to a constant weight. The residue was allowed to cool in a suitable desiccator for $30 \mathrm{~min}$ and weight was taken without delay. The amount of acid-insoluble ash was calculated with reference to the air-dried drug.

2.4.3 Determination of alcohol and water soluble matter (Anonymous, 2005, 2010)

$5 \mathrm{~g}$ of the sample of IHA was macerated with $100 \mathrm{ml}$ of distilled water and $100 \mathrm{ml}$ of ethyl alcohol of a specified strength, respectively in a closed flask for $24 \mathrm{~h}$, subjected to frequent shaking on the orbital shaker for $6 \mathrm{~h}$ and then allowed to stand for $18 \mathrm{~h}$ and was filtered rapidly, taking precautions to avoid solvent loss. $25 \mathrm{ml}$ of the filtrate was evaporated to dry in a tared flat bottomed shallow dish, and was then dried at $105^{\circ} \mathrm{C}$, to constant weight and then cooled in desiccator for $30 \mathrm{~min}$ then weighed. The percentage of alcohol and water soluble extractive values were calculated with reference to the air-dried drug.

$2.4 .4 \mathrm{pH}$ of $1 \%$ and $10 \%$ aqueous suspension (Anonymous, 2005, 2010)

Accurately weigh 1 and $10 \mathrm{~g}$ of IHA from each batch separately and add $100 \mathrm{ml}$ of distilled water make $1 \%$ and $10 \%$ aqueous suspension, respectively. The suspensions were used to determine the $\mathrm{pH}$ using the $\mathrm{pH}$ meter.

\subsubsection{Bulk density}

A cylinder of $25 \mathrm{ml}$ was taken and weighed empty and also weighed with $10 \mathrm{ml}$ of distilled water and the level of upper and lower meniscus was carefully marked, the cylinder was then emptied and dried after rinsing it with acetone. The bottle was then filled carefully with IHA and allowed to settle, then filled again to make the level up to the mark and weighed. Bulk density was then calculated with reference to the weight of water and the drug. The process was repeated for all three batches. Bulk density= mass of $\mathrm{drug} / \mathrm{bulk}$ volume. (Anonymous, 2005, 2010)

\subsubsection{Estimation of sugars}

The reducing and non-reducing sugars in IHA was estimated as per the standard method reported in Unani Pharmacopoeia of India (Anonymous, 2005, 2010) CCRUM, Ministry of Health and Family welfare, Govt. of India.

\subsection{High performance thin layer chromatography (HPTLC)}

\subsubsection{Preparation of drug extract for the procedure}

Sample of IHA was weighed $5 \mathrm{~g}$ and then refluxed with $200 \mathrm{ml}$ of alcohol using soxhlet apparatus on water bath for $30 \mathrm{~min}$. The extract obtained was then filtered and was concentrated to $5 \mathrm{ml}$. The extract, thus obtained was used for thin-layer chromatography. The obtained concentrated extract was applied on the pre-coated silica gel thin aluminium TLC plates (Anonymous, 2010; Rasheed et al., 2010; Rasheed et al., 2017; Zafar et al., 2020).

\subsubsection{Development of solvent system}

Solvent systems were tried in variable volume ratios, viz., toluene: ethyl acetate (9:1), toluene: ethyl acetate (7:3), toluene: ethyl acetate: ethyl formate: formic acid (6:2:1:1), toluene: ethyl acetate: methanol (5:3:2), toluene: ethyl acetate: methanol (7:2:1) of which the suitable solvent system was found in ratio as toluene: ethyl acetate: methanol 7:2:1 $(v / v / v)$ and developed in the twin through chamber of TLC to the $80 \mathrm{~mm}$ height of the TLC plate in order to separate the components on the polar phase of silica gel and to that of the mobile phase. The $\mathrm{R}_{f}$ values of the spots are calculated as $\mathrm{R}_{f}=$ Distance travelled by the spot/distance travelled by the solvent front.

\subsubsection{High performance thin layer chromatography (HPTLC)}

DESAGA Sarstedt Gruppe system (Germany) HPTLC instrument, along with automatic TLC applicator and UV visible cabinet as an imaging system was used for the analysis and proquant 1.6 version software system. After developing the TLC plate was air-dried and detected with the suitable detection system like UV cabinet system 
for detection of spots at $366 \mathrm{~nm}, 254 \mathrm{~nm}$ and also under iodine vapors and after derivatising with anisaldehyde sulfuric acid reagent. Further, it was scanned with the densitometer (CD60 of DESAGA Sarstedt Gruppe system) in order to obtain the densitogram.

\subsubsection{HPTLC method conditions}

For HPTLC, desaga sarstedt gruppe (made in Germany) was used for the HPTLC, Twin-trough development chamber $(20 \times 10 \mathrm{~cm})$ was employed. Pre-coated silica gel $60 \mathrm{~F}_{254}$ (aluminium plates Merck, KgaA, Germany) was used as stationary phase with Plate thickness $0.2 \mathrm{~mm}$, size $200 \times 100 \mathrm{~mm}$. The distance from starting on TLC plate on $\mathrm{x}$-axis was $20 \mathrm{~mm}$ and on y-axis $10 \mathrm{~mm}$, Volume of the extract applied was $5 \mu 1.10 \mathrm{~mm}$ was the band length and distance between tracks was $20 \mathrm{~mm}$. The development distance was $80 \mathrm{~mm}$ with the mobile phase as toluene: ethyl acetate: methanol $(7: 2: 1, v / v / v)$.

\subsection{Phytochemical tests for constituents}

Phytochemical screening was carried out in aqueous chloroform and alcoholic extracts of IHA. The extract was subjected to various qualitative phytochemical tests (Anonymous, 2005; Rasheed et al., 2012a; Rasheed et al., 2012b; Bhushan Mishra, 2019), such as alkaloids, carbohydrates, phenols, glycosides, tannins, steroids, fixed oils, flavonoids, starch, proteins, etc. For qualitative analysis of alkaloids, dragendorff test, mayer test, hager test and wagner test were carried out; for carbohydrates-fehling test, molish test, benedict's test and tollens test were carried out. For fixed oils, filter paper test was performed. For glycosides, a small amount of drug extract was dissolved in $1 \mathrm{ml}$ of water, aqueous sodium hydroxide solution was then added and observed for the color change. For phenols, ferric chloride test, lead acetate test and liebermann test were carried out. For resins, a small quantity of chloroform and ethanol extract was dissolved in $5-10 \mathrm{ml}$ of acetic anhydride by means of gentle heat, it was then cooled and $0.05 \mathrm{ml}$ of sulphuric acid was added, and observed for colour change. For saponins, about $5 \mathrm{ml}$ of aqueous drug extract was taken in a test tube add a drop of sodium bicarbonate solution, the mixture was then vigorously shaken and left for $3 \mathrm{~min}$ and observed for the formation of honey comb like froth. For the test of protein, millon test and biuret test were conducted. For starch, $0.015 \mathrm{~g}$ of iodine and $0.075 \mathrm{~g}$ of potassium iodide was dissolved in $5 \mathrm{ml}$ of distilled water, and added 2-3 $\mathrm{ml}$ of an aqueous extract of the drug and observed for color change. For steroids test, liebermann-burchard test, salkowski test were conducted. The test for tannins was done using ferric chloride test and lead acetate test. For the test of flavonoids, $0.5 \mathrm{ml}$ of alcoholic drug extract in a test tube and add 5-10 drops of dilute hydrochloric acid, followed by a small piece of zinc or magnesium. The solution was then boiled for few minutes and observed for a colour change.

\subsection{Microbial load determination}

The microbial load analysis was performed as per the guidelines of UPI and WHO (Anonymous, 1996, 2010; WHO, 2011). Analytical measures and media, all analytical measures in this study are according to the UPI, Vol-II, Part-II; IP (Anonymous, 1996) and WHO (Anonymous, 2010; WHO, 2011), soybean casein digest agar media (Gunn et al., 1977). Sabouraud dextrose agar with chloramphenicol media: (Forbes et al., 2007) HiCrome ${ }^{\mathrm{TM}}$ E. coli agar media: (Anderson and Baird Parker, 1975; Hitchins and Jinneman, 1998). HiCrome rajhans medium, modified/salmonella agar, modified (Hansen and Yourassowsky, 1984; Rambach, 1990) were used (Anonymous, 1996 and 2010). Serial dilution of sample: $1 \mathrm{~g}$ each of the sample was weighed into a test-tube containing $9 \mathrm{ml}$ of sterile buffered sodium chloride-peptone solution and serially diluted them (1:10, 1:100, 1:100). Microbial count: The plate was counted at 24-48 $\mathrm{h}$ for soybean casein digest agar media, HiCrome E. coli agar media and modified Salmonella agar media while it was read for sabouraud dextrose agar media 48-72 $\mathrm{h}$.

\subsection{Aflatoxin analysis}

Several types of aflatoxin (14 or more) occur in nature, but four aflatoxins, B1, B2, G1 and G2 are particularly dangerous to humans and animals as they have been found in all major medicinal herbs. Aflatoxins are highly dangerous and extreme care should be exercised in handling aflatoxin materials. This test provides us to detect the possible presence of aflatoxins, B1, B2, G1 and G2 in any material of plant origin, unless otherwise specified in the individual monograph (Anonymous, 2010; Liu and Wu, 2010). Aflatoxin was evaluated by the thin layer chromatography method, dissolved and accurately weighed quantities of aflatoxin, B1, B2, G1 and G2 in a mixture of chloroform and acetonitrile $(9.8: 0.2, v / v)$ to obtain a solution having concentrations of $0.5 \mu \mathrm{g} / \mathrm{ml}$, each for aflatoxin, B1 and $\mathrm{G} 1$, and $0.1 \mu \mathrm{g}$ per $\mathrm{ml}$ each for aflatoxins for B2 and G2.

\subsection{Heavy metals analysis}

Determination of heavy metals like lead, cadmium, arsenic and mercury in IHA was analyzed at Drug Standardization Research Institute (DSRI), Ghaziabad, India with the help of Atomic absorption spectrophotometer as per the standard methods prescribed in Anonymous (2010) and WHO (2011).

\subsection{Pesticides residue analysis}

Pesticide residue analysis for IHA was done through validated test method R-44 at Bureau Veritas India testing services, private limited, Sanath Nagar Hyderabad, Telangana for various pesticide residual analysis whose results are mentioned in the Table 12 .

Table 2: Organoleptic properties IHA

\begin{tabular}{|l|l|l|l|l|}
\hline S.No. & Organoleptic properties & Batch 1 & Batch 2 & Batch 3 \\
\hline 1 & Appearance & Semi solid & Semi solid & Semi solid \\
2 & Color & Deep blackish brown & Deep blackish brown & Deep blackish brown \\
3 & Odour & Pleasant & Pleasant & Pleasant \\
4 & Texture & Slightly rough & Slightly rough & Slightly rough \\
5 & Taste & Sweet and astringent & Sweet and astringent & Sweet and astringent \\
\hline
\end{tabular}




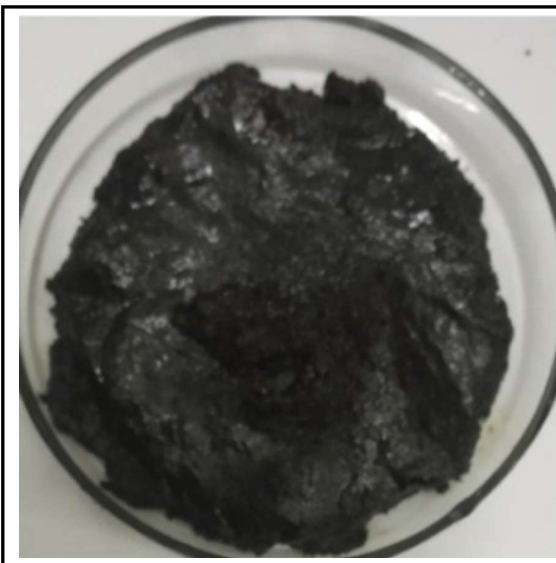

Batch 1 (IHA sample)

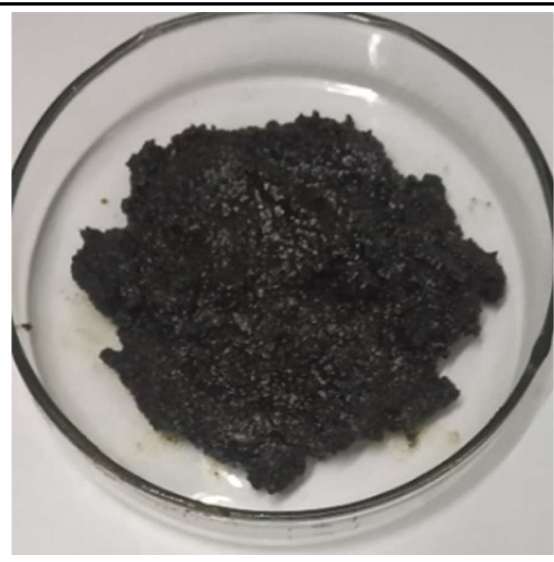

Batch 2 (IHA sample)

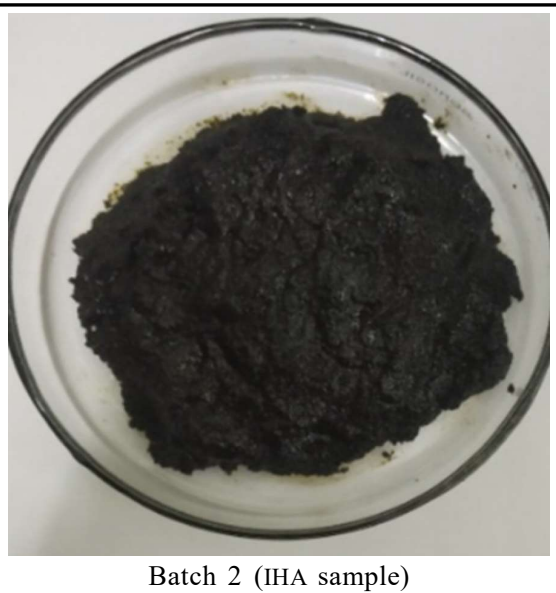

Batch 2 (IHA sample)

Figure 2: Samples of IHA from batch 1, batch 2 and batch 3 .

\section{Results}

\subsection{Organoleptic properties}

The organoleptic properties of IHA in all three batches were recorded as deep blackish-brown colored, semisolid form with pleasant odour, sweet and astringent in taste and slightly rough in texture. The organoleptic properties of IHA as shown in Table 2 and the prepared formulations are shown in Figure 2.

\subsection{Microscopy of IHA}

On the microscopic examination of IHA, different characters such as straight walled epidermal cells in surface view, fragments of spiral vessels elements, xylem fibers embedded in the parenchymatous cells, thick porous walls containing oil globules and simple oval to spherical starch grains, tracheids and stone cell were observed (Figures $3 \mathrm{a}$ to $3 \mathrm{~h}$ ).

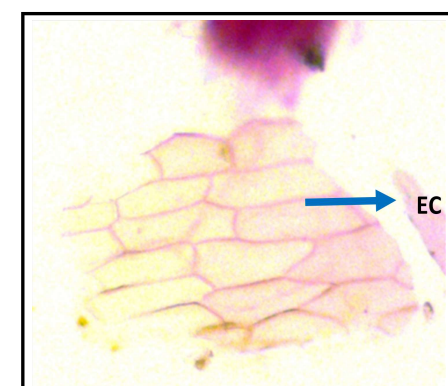

3a. Epidermal cells (EC)

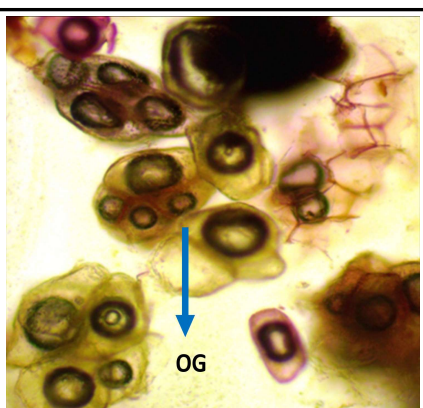

3b. Oil Globules (OG)

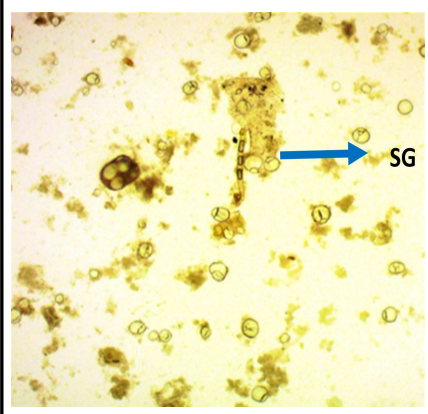

3e. Starch Grains (SG)

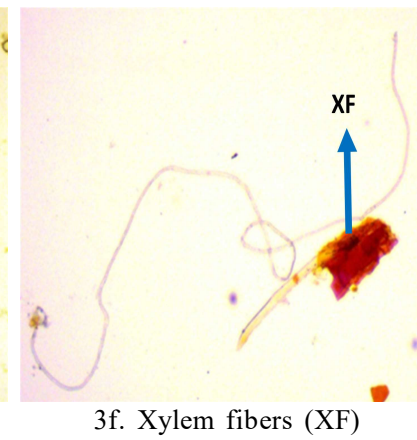

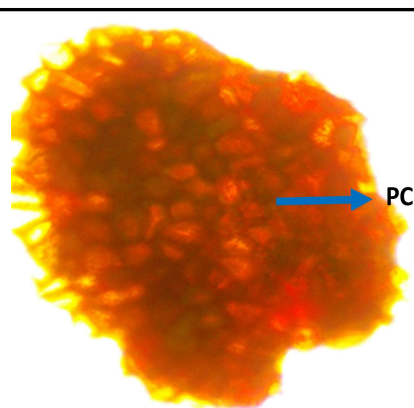

3c. Parenchymatous cells (PC)

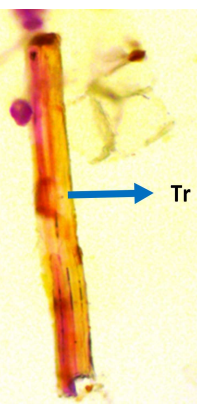

3g. Tracheids (Tr)

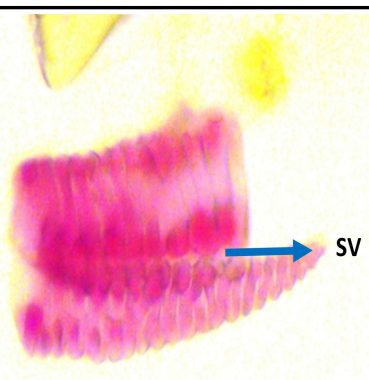

3d. Spiral vessels (SV)

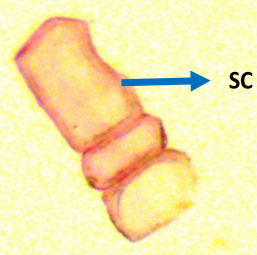

3h. Stone cell (SC)

Figure 3(a-h): Microscopy of IHA.

\subsection{Physicochemical parameters}

The mean value of the various physicochemical parameters evaluated was expressed as the mean of the three readings calculated for the sample from each batch. The ash is the residue remaining after incineration and an important parameter in the quality control of herbal drugs. The mean percentage of total ash and acid insoluble ash values of IHA were found in the range of

1.3357 to $1.3666 \% w / w$ and 0.1494 to $0.1806 \% w / w$, respectively in three different batches. Percentage loss of weight on drying (LOD) at $105^{\circ} \mathrm{C}$ is an indicative for loss of volatile contents along with the moisture content in the drug. The percentage of LOD was calculated for the three different batches was found in the range of 17.0550 to $17.0782(\% \mathrm{w} / \mathrm{w})$ as given in Table 3 and Figures 4-6. 


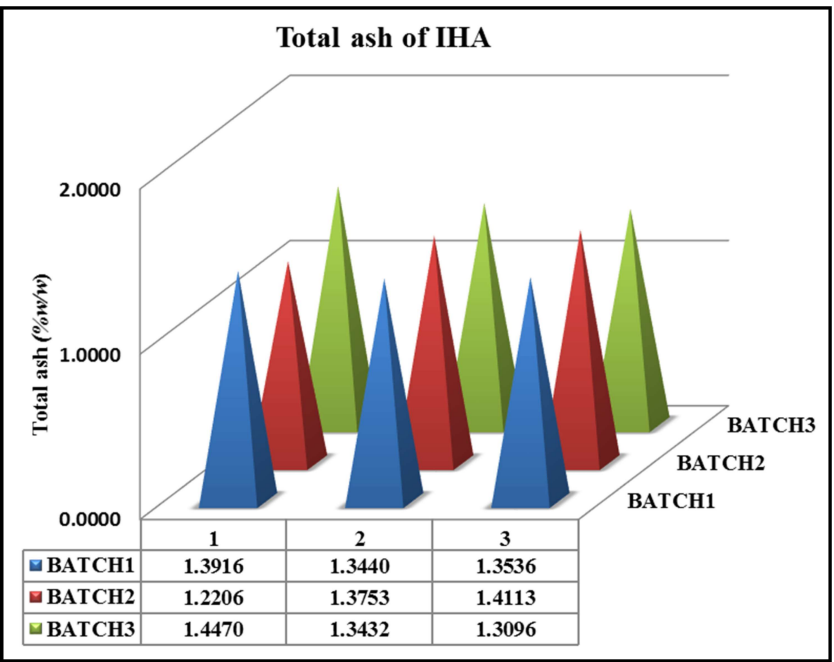

Figure 4: Total ash of IHA.

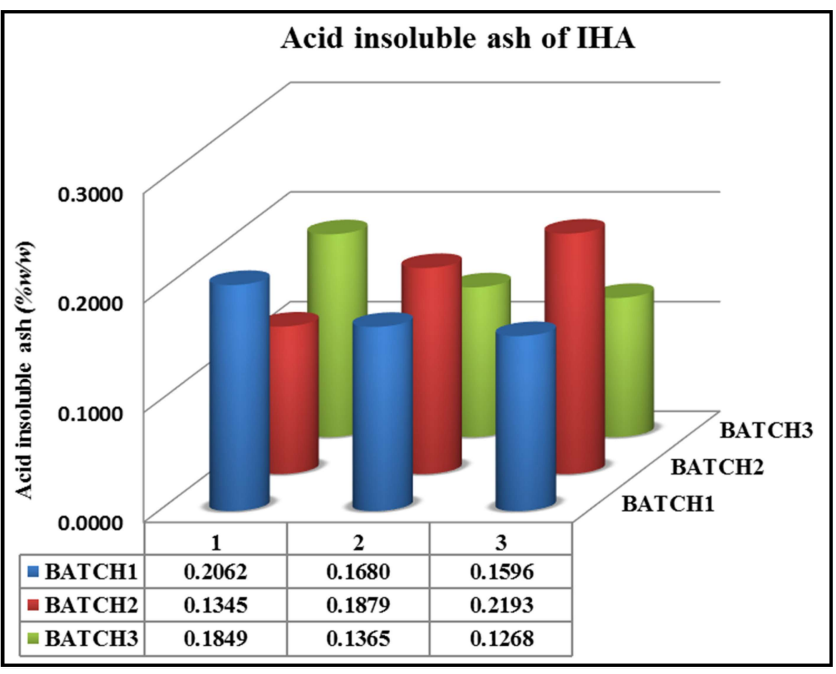

Figure 5: Acid insoluble ash of IHA.

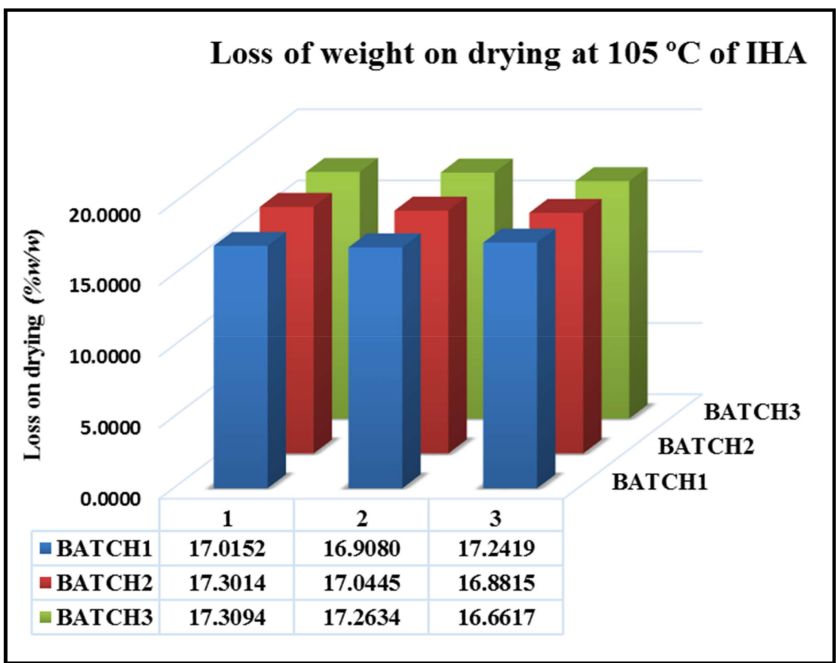

Figure 6: Loss of weight on drying at $105^{\circ} \mathrm{C}$.

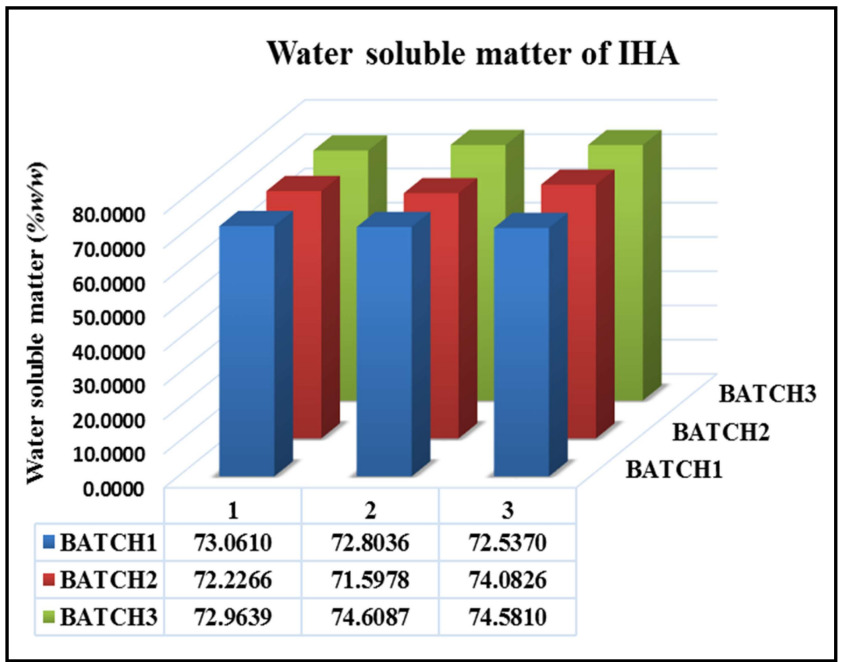

Figure 7: Water soluble matter of IHA.

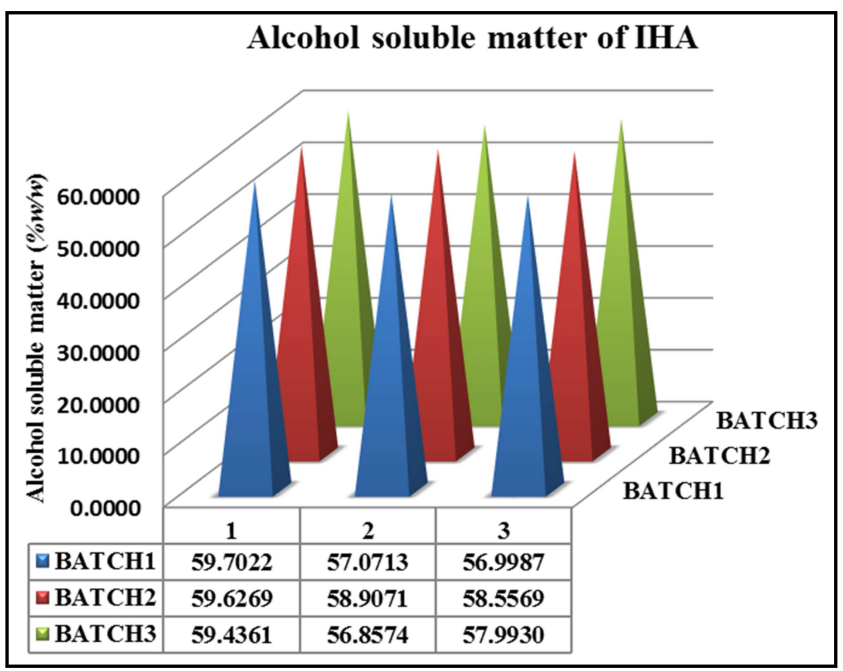

Figure 8: Alcohol soluble matter of IHA.

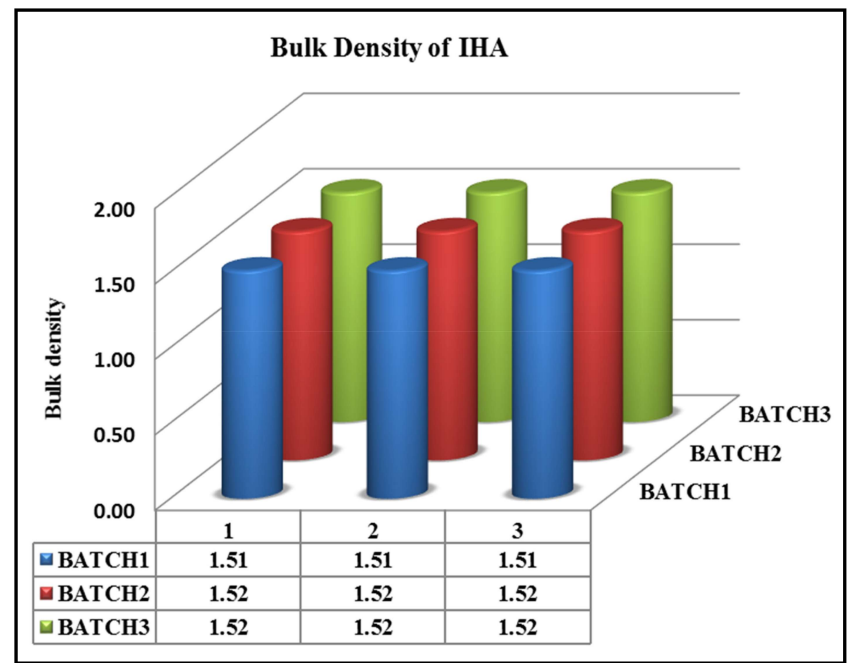

Figure 9: Bulk density of IHA. 


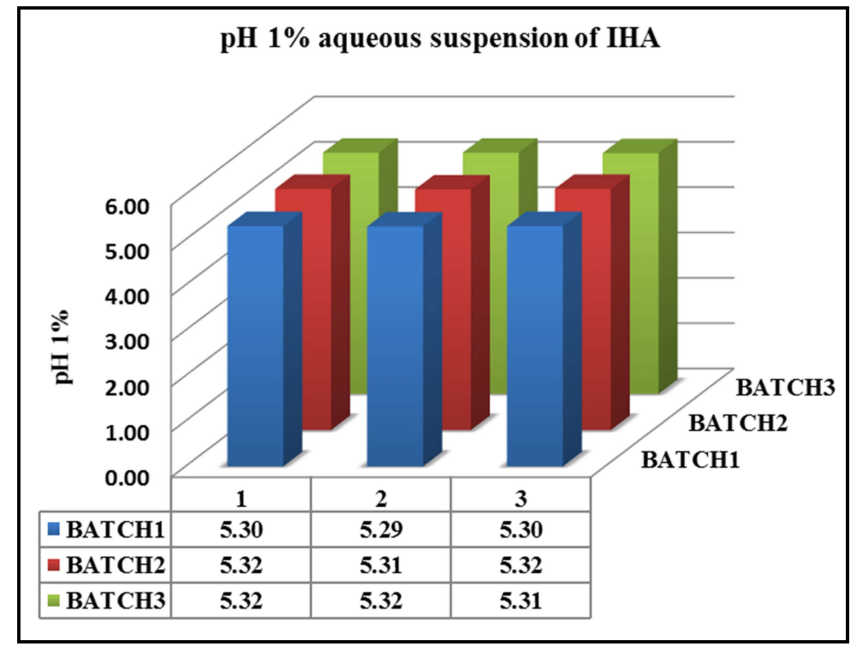

Figure 10: pH 1\% aqueous suspension of IHA.

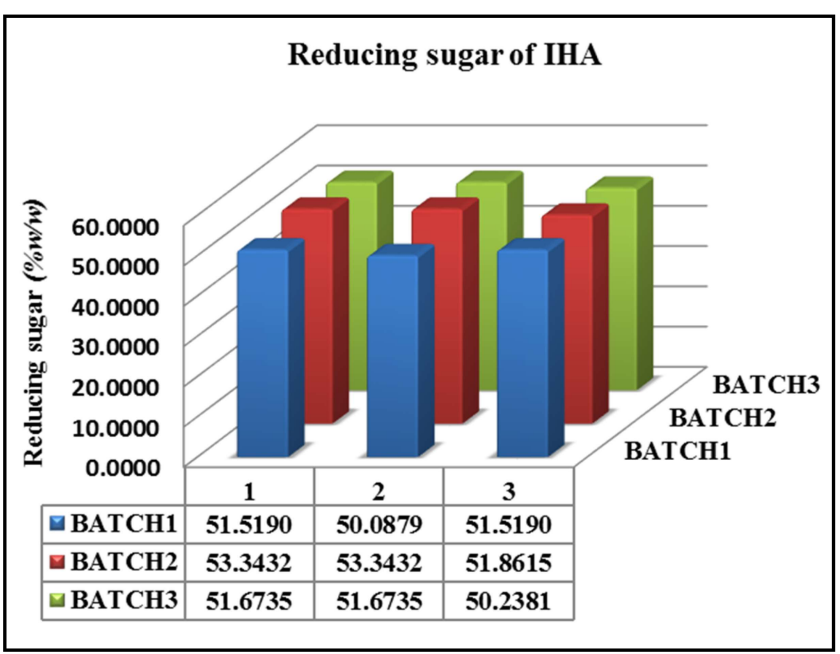

Figure 12: Reducing sugar - IHA.

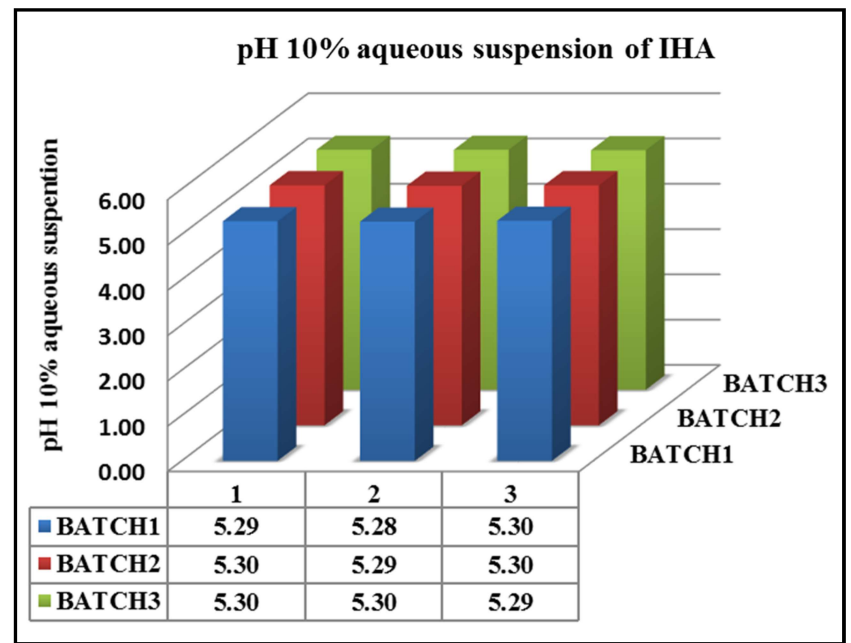

Figure 11: pH 10\% aqueous suspension of IHA.

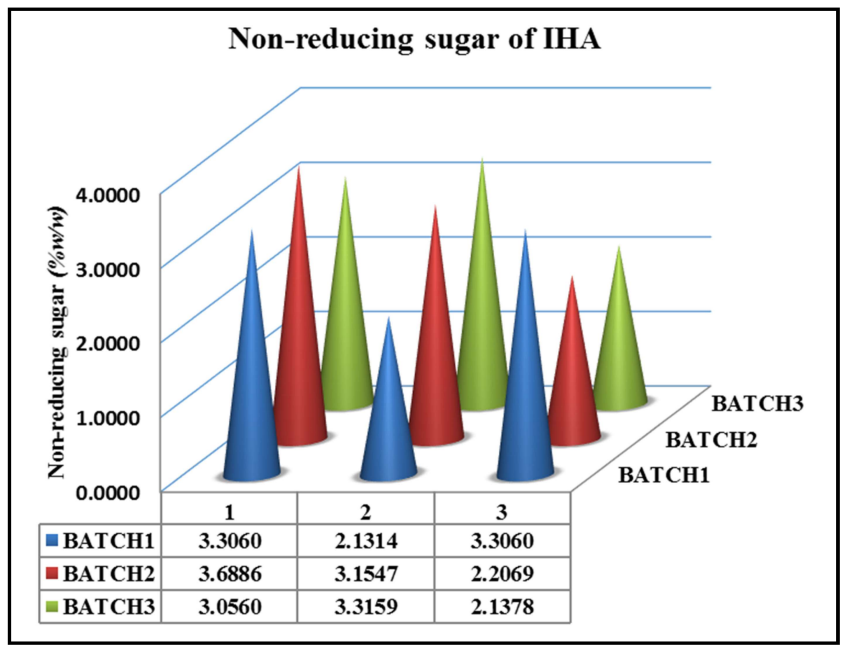

Figure 13: Non-reducing sugar - IHA.

Table 3: Physico chemical parameters

\begin{tabular}{|c|c|c|c|c|}
\hline S.No. & Parameters & Batch $1($ Mean \pm SD $)$ & Batch $2($ Mean \pm SD) & Batch $3($ Mean $\pm S D)$ \\
\hline $\begin{array}{l}1 \\
2 \\
3 \\
4 \\
5 \\
6 \\
7 \\
8 \\
9 \\
10\end{array}$ & $\begin{array}{l}\text { Total ash }(\% w / w) \\
\text { Acid insoluble ash }(\% w / w) \\
\text { Loss of weight on drying at } 105^{\circ} \mathrm{C}(\% w / w) \\
\text { Water soluble matter }(\% w / w) \\
\text { Alcohol soluble matter }(\% w / w) \\
\text { Bulk density } \\
\text { pH } 1 \% \text { aqueous suspension } \\
\text { pH } 10 \% \text { aqueous suspension } \\
\text { Reducing sugar }(\% w / w) \\
\text { Non reducing sugar }(\% w / w)\end{array}$ & $\begin{aligned} 1.3631 & \pm 0.03 \\
0.1779 & \pm 0.02 \\
17.0550 & \pm 0.17 \\
72.8005 & \pm 0.26 \\
57.9241 & \pm 1.54 \\
1.51 & \pm 0.00 \\
5.30 & \pm 0.01 \\
5.29 & \pm 0.01 \\
51.0419 & \pm 0.83 \\
2.9145 & \pm 0.68\end{aligned}$ & $\begin{aligned} 1.3357 & \pm 0.10 \\
0.1806 & \pm 0.04 \\
17.0758 & \pm 0.21 \\
72.6357 & \pm 1.29 \\
59.0303 & \pm 0.55 \\
1.52 & \pm 0.00 \\
5.32 & \pm 0.01 \\
5.30 & \pm 0.01 \\
52.8493 & \pm 0.86 \\
3.0167 & \pm 0.75\end{aligned}$ & $\begin{aligned} 1.3666 & \pm 0.07 \\
0.1494 & \pm 0.03 \\
17.0782 & \pm 0.36 \\
74.0512 & \pm 0.94 \\
58.0955 & \pm 1.29 \\
1.52 & \pm 0.00 \\
5.32 & \pm 0.01 \\
5.30 & \pm 0.01 \\
51.1950 & \pm 0.83 \\
2.8366 & \pm 0.62\end{aligned}$ \\
\hline
\end{tabular}

The mean percentage of water soluble matter and alcohol soluble matter of IHA was found in the range of 72.6357 to $74.0512 \% \mathrm{w} / \mathrm{w}$ and 57.9241 to $59.0303 \% w / w$, respectively in three different batches (Table 3 and Figures 7-8).

The bulk density is also known as volumetric density or apparent density. Bulk density of a drug is defined as weight per unit volume. Bulk density was around 1.51-1.52 (Table 3 and Figure 9).
The mean value of $\mathrm{pH}$ of $1 \%$ aqueous suspension and of $10 \%$ aqueous suspension of IHA was found in the range of 5.30 to 5.32 and 5.29 to 5.30, respectively in three different batches (Table 3 . and Figures 10-11).

$\mathrm{pH}$ value is useful practical means to the qualitative indication of the acidity or alkalinity of a solution. The $\mathrm{pH}$ of aqueous for $1 \%$ as well as $10 \%$ suspension of IHA was found in acidic range is acidic in nature and, hence implies less chances of contamination. 
Estimation of sugar values are helpful in setting up the standards for sugar syrup based formulation. The mean percentage of reducing sugar and non-reducing sugar was found in the range of 51.0419 to 52.8493 and 2.8366 to 3.0167 , respectively as presented in Table 3 and Figures 12-13.

\subsection{Phytochemical analysis}

The pharmacological actions of a drug was due to the presence of various phytochemicals in it. The qualitative test performed for IHA to detect various class of compound such as alkaloids, carbohydrates, fixed oil, glycosides, phenols, resin, saponins, protein, starch, steroids, tannins, etc. The inference observed for the respective phytochemical test, and the results were recorded as shown in Table 4.

Table 4: Qualitative phytochemical screening of IHA

\begin{tabular}{|c|c|c|c|c|}
\hline \multirow[t]{2}{*}{ S.No. } & \multirow[t]{2}{*}{ Phytochemical constituents } & \multicolumn{3}{|c|}{ Inferences } \\
\hline & & alcoholic extract & chloroform extract & aqueous extract \\
\hline $\begin{array}{l}1 \\
2 \\
3 \\
4 \\
5 \\
6 \\
7 \\
8 \\
9 \\
10 \\
11 \\
12\end{array}$ & \begin{tabular}{|l} 
Alkaloid \\
Carbohydrate \\
Fixed oil \\
Glycosides \\
Phenols \\
Resins \\
Saponins \\
Proteins \\
Starch \\
Steroids \\
Tannins \\
Flavonoids
\end{tabular} & $\begin{array}{c}++ \\
+ \\
- \\
+ \\
+++ \\
- \\
- \\
++ \\
- \\
++ \\
++ \\
++\end{array}$ & $\begin{array}{l}- \\
- \\
- \\
+ \\
- \\
- \\
- \\
- \\
- \\
+ \\
- \\
+\end{array}$ & $\begin{array}{c}++ \\
++ \\
- \\
+ \\
+++ \\
- \\
+ \\
++ \\
- \\
++ \\
+++ \\
++\end{array}$ \\
\hline
\end{tabular}

Note: $+++=$ high, $++=$ moderate,$+=$ low, $-=$ absent

\subsection{HPTLC analysis of alcoholic extract of IHA}

$5 \mathrm{~g}$ of IHA, accurately weighed and refluxed with $200 \mathrm{ml}$ of alcohol using soxhlet apparatus on a water-bath for $30 \mathrm{~min}$. Filter the extract and concentrated to $5 \mathrm{ml}$, the sample, thus obtained was used for thin layer chromatography. The alcoholic extract of formulation from three different batches was applied on TLC plate and developed in the TLC development chamber.

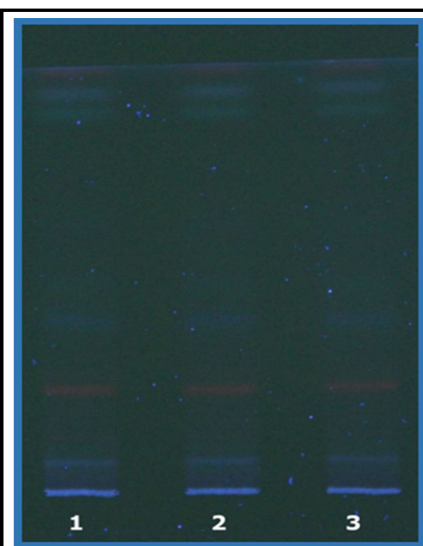

14a. At UV 366nm

(Track 1,2,3 represents

formulation batches $1,2,3$ )

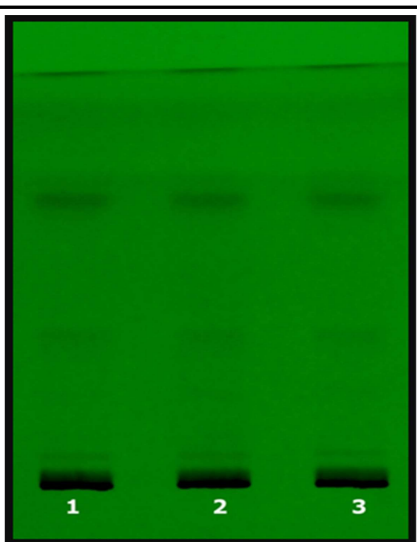

14b. At UV $254 \mathrm{~nm}$

(Track 1,2,3 represents formulation batches $1,2,3$ )

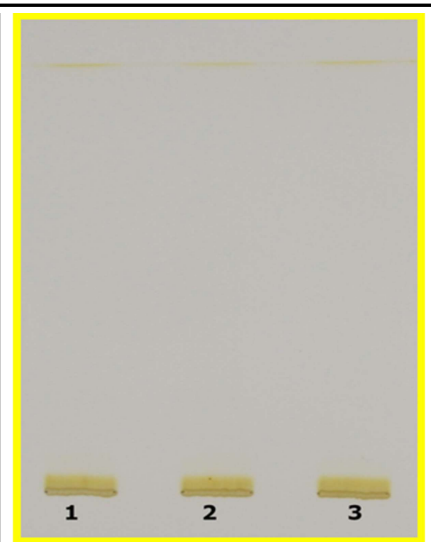

14c. on exposure to iodine vapour

(Track 1,2,3 represents

formulation batches $1,2,3$ )

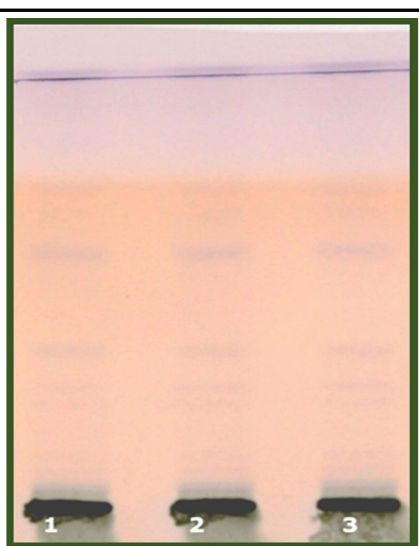

14d. After derivatization with anisaldehyde sulphuric acid reagent (Track 1,2,3 represents formulation batches $1,2,3$ )

Figure 14: TLC plates showing three batches of formulations photographed at (14a.) UV $366 \mathrm{~nm}$, (14b.) UV 254 nm, (14c.) on exposure to iodine vapour, (14d.) after derivatization with anisaldehyde sulphuric acid reagent.

Alcoholic extract was spotted on silica gel ' $G$ ' plate and developed with toluene: ethyl acetate: methanol $(7: 2: 1, v / v / v)$ as mobile phase shows six major spots under UV $366 \mathrm{~nm}$ at $\mathrm{R}_{f}$ values 0.07 (light blue), 0.24 (red), 0.39 (light blue), 0.90 (light blue), 0.94 (light blue), 0.99 (red); and under UV $254 \mathrm{~nm}$ shows five spots at $\mathrm{R}_{f}$ values 0.03, 0.07, 0.36, 0.67, 0.99 (All black); and under iodine vapours shows two spots at $\mathrm{R}_{f}$ values $0.04,0.99$ (both brown); and under anisaldehyde sulphuric acid reagent and heating at $105^{\circ} \mathrm{C}$ shows four spots at $\mathrm{R}_{f}$ values 0.03 (purple), 0.36 (purple), 0.61 (purple), 0.99 (purple). Further, the HPTLC analysis was carried out using the same detection system, and the mobile phases and the corresponding densitogram were recorded, in which different peak are observed for the spots appeared in the TLC plate. Each peak area was recorded using the HPTLC instrument. The corresponding data for peak areas as detected in HPTLC densitogram as represented in the table 5-8 and in Figures 14a-14d, 15-18. 
Table 5: Peak list of alcoholic extract of IHA at UV $366 \mathrm{~nm}$.

\begin{tabular}{|l|l|r|l|r|l|}
\hline Peak No. & Y-Pos & \multicolumn{1}{|l|}{ Area } & Area \% & Height & R $_{\boldsymbol{f}}$ value \\
\hline 1 & 10.6 & 1533.36 & 89.49 & 581.79 & 0.02 \\
2 & 15.1 & 100.78 & 5.88 & 59.13 & 0.08 \\
3 & 26.7 & 19.75 & 1.15 & 10.84 & 0.25 \\
4 & 36.6 & 7.41 & 0.43 & 3.82 & 0.38 \\
5 & 50.0 & 3.71 & 0.22 & 3.19 & 0.57 \\
6 & 72.6 & 5.62 & 0.33 & 5.04 & 0.88 \\
7 & 79.6 & 42.80 & 2.50 & 19.57 & 0.98 \\
\hline
\end{tabular}

Table 6: Peak list of alcoholic extract of IHA at UV $366 \mathrm{~nm}$.

\begin{tabular}{|l|l|r|r|r|l|}
\hline Peak No. & Y-Pos & \multicolumn{1}{|l|}{ Area } & Area \% & Height & R $_{f}$ value \\
\hline 1 & 10.4 & 2579.30 & 70.89 & 1104.39 & 0.02 \\
2 & 15.0 & 91.88 & 2.53 & 59.69 & 0.08 \\
3 & 18.4 & 4.51 & 0.12 & 4.40 & 0.13 \\
4 & 25.3 & 2.64 & 0.07 & 3.45 & 0.23 \\
5 & 35.6 & 162.35 & 4.46 & 59.05 & 0.37 \\
6 & 58.6 & 699.56 & 19.23 & 176.64 & 0.69 \\
7 & 80.1 & 98.24 & 2.70 & 90.34 & 0.99 \\
\hline
\end{tabular}

Table 7: Peak list of alcoholic extract of IHA upon exposure to iodine vapours.

\begin{tabular}{|l|l|r|l|l|l|}
\hline Peak No. & Y-Pos & Area & Area \% & Height & R $_{\boldsymbol{f}}$ value \\
\hline 1 & 10.4 & 809.40 & 96.89 & 325.04 & 0.02 \\
2 & 26.2 & 6.15 & 0.74 & 3.02 & 0.24 \\
3 & 80.5 & 19.81 & 2.37 & 15.92 & 0.99 \\
\hline
\end{tabular}

Table 8: Peak list of alcoholic extract of IHA upon derivatization with anisaldehyde sulphuric acid reagent at $580 \mathrm{~nm}$.

\begin{tabular}{|l|l|r|r|r|l|}
\hline Peak No. & Y-Pos & Area & Area \% & Height & $\mathbf{R}_{f}$ value \\
\hline 1 & 10.7 & 6310.56 & 81.38 & 2276.57 & 0.02 \\
2 & 27.3 & 20.48 & 0.26 & 12.91 & 0.25 \\
3 & 30.1 & 32.87 & 0.42 & 20.82 & 0.29 \\
4 & 36.0 & 94.78 & 1.22 & 36.90 & 0.38 \\
5 & 51.9 & 172.52 & 2.22 & 66.31 & 0.60 \\
6 & 62.4 & 66.12 & 0.85 & 28.77 & 0.74 \\
7 & 80.6 & 1056.98 & 13.63 & 449.64 & 0.99 \\
\hline
\end{tabular}

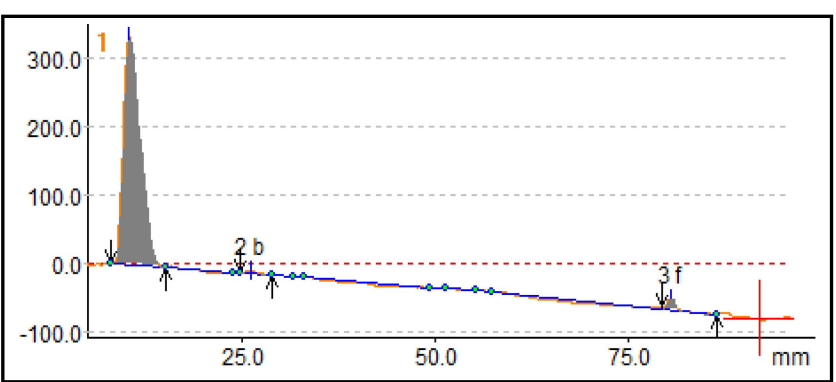

Figure 15: Densitogram of alcoholic extract of IHA upon exposure to iodine vapours.

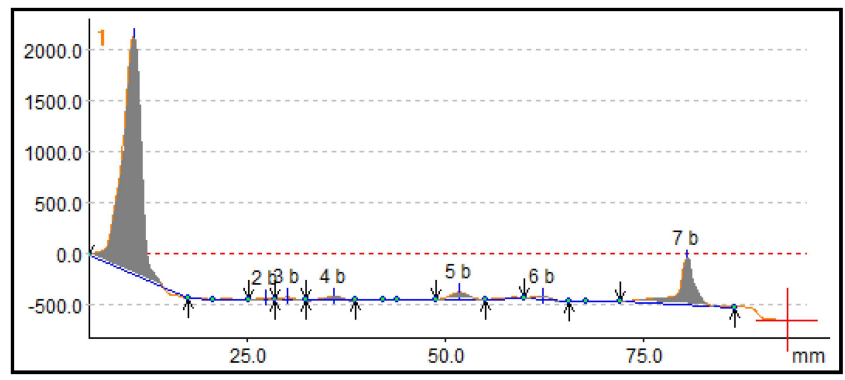

Figure 16: Densitogram of alcoholic extract of IHA upon derivatized with anisaldehyde sulphuric acid reagent.

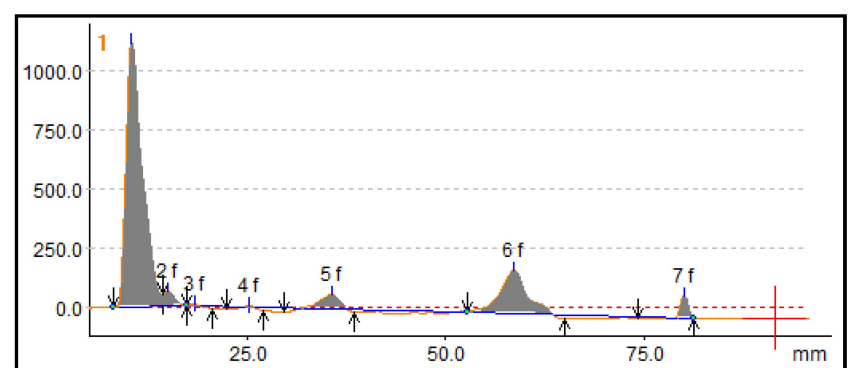

Figure 17: Densitogram of alcoholic extract of IHA at UV $254 \mathrm{~nm}$.

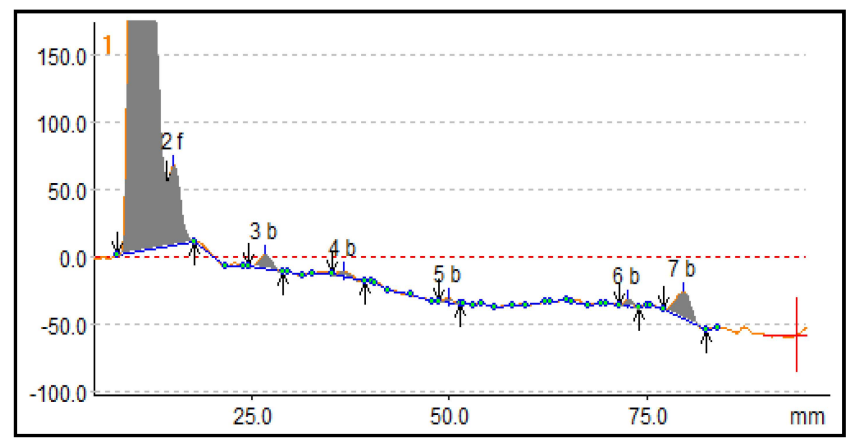

Figure 18: Densitogram of alcoholic extract of IHA at UV $366 \mathrm{~nm}$.

\subsection{Test for microbial load and specific pathogen contamination}

Up to 1500 species of bacteria have been isolated as bacteria are living things; they obtain a source of food, moisture and appropriate temperature to grow, when these conditions are ample. Total bacterial count in samples of IHA were found within the permissible limit as per WHO standard; specific pathogen like E. coli, Salmonella spp. are not present and total fungal count was nil in all sample. The data obtained as represented in Table 9.

Total bacterial count in samples of IHA were found within the range as per WHO standards and total fungal count was nil in samples 1, 2 and 3. Specific pathogen like E. coli, Salmonella spp. were also not present in the sample. Aflatoxin is the toxin produce by fungus Aspergillus varieties which is hepatotoxic. WHO has set permissible limits for the aflatoxin in herbal drugs. No aflatoxins (B1, B2, G1 and G2) were detected in IHA (Table 10). 
Table 9: Results of microbial load contamination analysis

\begin{tabular}{|l|l|c|c|c|l|}
\hline S.No. & Parameter analyzed & \multicolumn{3}{|c|}{ Results } & Permissible limit as per WHO \\
\cline { 3 - 5 } & & Batch 1 & Batch 2 & Batch 3 & \\
\hline 1 & Total bacterial count & $18 \times 10^{3}$ & $22 \times 10^{3}$ & $20 \times 10^{3}$ & Not $\mathrm{more}$ than $10^{5} / \mathrm{g}$ \\
2 & E. coli & $\mathrm{Nil}$ & $\mathrm{Nil}$ & $\mathrm{Nil}$ \\
3 & Salmonella spp. & $\mathrm{Nil}$ & $\mathrm{Nil}$ & $\mathrm{Nil}$ & $\mathrm{Nil}$ \\
4 & Total fungal count & $\mathrm{Nil}$ & $\mathrm{Nil}$ & $\mathrm{Nil}$ & Not more than $10^{3} / \mathrm{g}$ \\
\hline
\end{tabular}

Table 10: Results of aflatoxin determination

\begin{tabular}{|c|c|c|c|c|c|}
\hline \multirow[t]{2}{*}{ S.No. } & \multirow[t]{2}{*}{ Parameter analyzed } & \multicolumn{3}{|c|}{ Results } & \multirow[t]{2}{*}{ Permissible limit as per WHO } \\
\hline & & Batch 1 & Batch 2 & Batch 3 & \\
\hline $\begin{array}{l}1 \\
2 \\
3 \\
4\end{array}$ & $\begin{array}{l}\mathrm{B} 1 \\
\mathrm{~B} 2 \\
\mathrm{G} 1 \\
\mathrm{G} 2\end{array}$ & $\begin{array}{l}\text { Nil } \\
\text { Nil } \\
\text { Nil } \\
\text { Nil }\end{array}$ & $\begin{array}{l}\text { Nil } \\
\text { Nil } \\
\text { Nil } \\
\text { Nil }\end{array}$ & $\begin{array}{l}\text { Nil } \\
\text { Nil } \\
\text { Nil } \\
\text { Nil }\end{array}$ & $\begin{array}{l}\text { Not more than } 0.50 \mathrm{ppm} \\
\text { Not more than } 0.10 \mathrm{ppm} \\
\text { Not more than } 0.50 \mathrm{ppm} \\
\text { Not more than } 0.10 \mathrm{ppm}\end{array}$ \\
\hline
\end{tabular}

\subsection{Estimation of heavy metals and pesticides residue}

Heavy metal estimation and estimation of pesticide residue is very important quality control parameter while performing the standardization of herbal drugs. There will be very toxic effects, if they are present in a drug above the standards set by WHO. Pesticide residue analysis for IHA was done through validated test method R-44 at Bureau Veritas India Testing Services, Private Limited, Sanath Nagar Hyderabad, Telangana. In this study, the pesticide residue (Table 12) as well as the heavy metals (Table 11) in IHA was found within the limits of safety as recommended by WHO.
Table 11: Results of heavy metals contamination

\begin{tabular}{|l|l|l|l|}
\hline S.No. & Parameter analyzed & Results & $\begin{array}{l}\text { WHO permissible } \\
\text { limits }\end{array}$ \\
\hline 1 & Lead $(\mathrm{Pb})$ & Not detected & $10 \mathrm{ppm}$ \\
2 & Cadmium $(\mathrm{Cd})$ & Not detected & $0.3 \mathrm{ppm}$ \\
3 & Arsenic $(\mathrm{As})$ & Not detected & $3.0 \mathrm{ppm}$ \\
4 & Mercury $(\mathrm{Hg})$ & Not detected & $1.0 \mathrm{ppm}$ \\
\hline
\end{tabular}

Table 12: Results of pesticides residue estimation

\begin{tabular}{|c|c|c|c|c|c|}
\hline \multirow[t]{2}{*}{ S.No. } & Test parameters & \multirow[t]{2}{*}{ Test method } & \multirow[t]{2}{*}{ UOM } & \multirow[t]{2}{*}{ LOQ } & \multirow[t]{2}{*}{ Test result } \\
\hline & Pesticide residue & & & & \\
\hline 1 & Alachlor & Validated test method & $\mathrm{mg} / \mathrm{kg}$ & 0.01 & BLQ \\
\hline 2 & Aldrin & Validated test method & $\mathrm{mg} / \mathrm{kg}$ & 0.01 & BLQ \\
\hline 3 & Dieldrin & Validated test method & $\mathrm{mg} / \mathrm{kg}$ & 0.01 & BLQ \\
\hline 4 & Azinphos-Methyl & Validated test method & $\mathrm{mg} / \mathrm{kg}$ & 0.01 & BLQ \\
\hline 5 & Bromopropylate & Validated test method & $\mathrm{mg} / \mathrm{kg}$ & 0.01 & BLQ \\
\hline 6 & Chlordane (sum of cis \& trans) & Validated test method & $\mathrm{mg} / \mathrm{kg}$ & 0.01 & BLQ \\
\hline 7 & Chlorfenvinphos & Validated test method & $\mathrm{mg} / \mathrm{kg}$ & 0.01 & BLQ \\
\hline 8 & Chlorpyrifos & Validated test method & $\mathrm{mg} / \mathrm{kg}$ & 0.01 & BLQ \\
\hline 9 & Chlorpyrifos-methyl & Validated test method & $\mathrm{mg} / \mathrm{kg}$ & 0.01 & BLQ \\
\hline 10 & Cypermethrin (\& isomers) & Validated test method & $\mathrm{mg} / \mathrm{kg}$ & 0.01 & BLQ \\
\hline 11 & DDT & Validated test method & $\mathrm{mg} / \mathrm{kg}$ & 0.01 & BLQ \\
\hline 12 & Deltametrin & Validated test method & $\mathrm{mg} / \mathrm{kg}$ & 0.01 & BLQ \\
\hline 13 & Diazinon & Validated test method & $\mathrm{mg} / \mathrm{kg}$ & 0.01 & BLQ \\
\hline 14 & Dichlorvos & Validated test method & $\mathrm{mg} / \mathrm{kg}$ & 0.01 & BLQ \\
\hline 15 & Dithiocarbamates & Validated test method & $\mathrm{mg} / \mathrm{kg}$ & 0.01 & BLQ \\
\hline 16 & Endosulfan & Validated test method & $\mathrm{mg} / \mathrm{kg}$ & 0.01 & BLQ \\
\hline 17 & Endrin & Validated test method & $\mathrm{mg} / \mathrm{kg}$ & 0.01 & BLQ \\
\hline 18 & Fenitrothion & Validated test method & $\mathrm{mg} / \mathrm{kg}$ & 0.01 & BLQ \\
\hline 19 & Fenvalerate & Validated test method & $\mathrm{mg} / \mathrm{kg}$ & 0.01 & BLQ \\
\hline 20 & Fonofos & Validated test method & - & & Absent \\
\hline 21 & Heptachlor & Validated test method & $\mathrm{mg} / \mathrm{kg}$ & 0.01 & BLQ \\
\hline 22 & Hexachlobenzene & Validated test method & $\mathrm{mg} / \mathrm{kg}$ & 0.01 & BLQ \\
\hline 23 & Hexachlorocyclohexane isomers (other than Alpha) & Validated test method & $\mathrm{mg} / \mathrm{kg}$ & 0.01 & BLQ \\
\hline 24 & Lindane & Validated test method & $\mathrm{mg} / \mathrm{kg}$ & 0.01 & BLQ \\
\hline 25 & Malathion & Validated test method & $\mathrm{mg} / \mathrm{kg}$ & 0.01 & BLQ \\
\hline 26 & Methidathion & Validated test method & $\mathrm{mg} / \mathrm{kg}$ & 0.01 & BLQ \\
\hline 27 & Parathion & Validated test method & $\mathrm{mg} / \mathrm{kg}$ & 0.01 & BLQ \\
\hline 28 & Parathion-Methyl & Validated test method & $\mathrm{mg} / \mathrm{kg}$ & 0.01 & BLQ \\
\hline 29 & Permethrin & Validated test method & $\mathrm{mg} / \mathrm{kg}$ & 0.01 & BLQ \\
\hline 30 & Phosalone & Validated test method & $\mathrm{mg} / \mathrm{kg}$ & 0.01 & BLQ \\
\hline 31 & Piperonyl Butoxide & Validated test method & $\mathrm{mg} / \mathrm{kg}$ & 0.01 & BLQ \\
\hline 32 & Pirimiphos-Methyl & Validated test method & $\mathrm{mg} / \mathrm{kg}$ & 0.01 & BLQ \\
\hline 33 & Pyrethrins & Validated test method & $\mathrm{mg} / \mathrm{kg}$ & 0.01 & BLQ \\
\hline 34 & Quintozone & Validated test method & $\mathrm{mg} / \mathrm{kg}$ & 0.01 & BLQ \\
\hline 35 & Ethion & Validated test method & $\mathrm{mg} / \mathrm{kg}$ & 0.01 & BLQ \\
\hline
\end{tabular}




\section{Discussion}

Assessment of organoleptic properties like appearance, colour, taste, texture and smell was carried out as its serves for quick identification and characterization. Microscopic assessments are usually limited to those formulations, in which the botanical ingredients are not more than 10 and where they are added in situ in powdered form as single drug ingredients (Anonymous, 2010). The microscopic examination of plant ingredients is essential for a number of solid and semi-solid medicinal formulations for quality control purposes. The microscopic evaluation is one of the method for authentication of raw material in order to examine the structural and cellular features of the herbs and to determine their botanical origin. IHA is a semisolid formulation having eight herbal drug ingredients. The ash value of a drug usually determines the inorganic substances present in it. The total ash is to estimate the overall quantity of material remaining after incerination which includes both physiological ash, i.e., derived from plant tissues and nonphysiological ash, i.e., residue from extraneous matter (WHO, 2011). Acid-insoluble ash is the residue obtained after boiling the total ash with dilute hydrochloric acid and igniting the remaining insoluble matter which measures the amount of silicaceous substances present (WHO, 2011). The higher the ash value indicates the higher amount of contamination, substitution, adulteration, or negligence in the preparation of drugs or drug formulation. These values were found to be reasonably low and there was a consistency in different batches. Estimation of solubility indicates the amount of dissolvable/ soluble constituents present in a drug. The soluble matter of the various drugs is specified and fixed. Therefore, for establishing drug standard of any drug, it plays an important role, hence the water soluble matter and alcohol soluble matter of IHA was done to set a standard. The bulk density is an important parameter in establishing the standards for a drug as different drugs can have different bulk densities depending on both the density of drug particles and the spatial arrangement of particles in a drug. The association between $\mathrm{pH}$ and microbial contamination indicates that neutral or alkaline $\mathrm{pH}$ favours high levels of microbial contamination of herbal preparations (Abba et al., 2009). The $\mathrm{pH}$ of aqueous for $1 \%$ as well as $10 \%$ suspension of IHA was found in acidic range is acidic in nature and, hence implies less chances of contamination. A number of polyherbal or herbomineral formulations in the Unani System of Medicine is prepared in the qiwam (base of sugar or honey), therefore, an estimation of sugar values is helpful in setting up the standards for such formulation. IHA was subjected to the phytochemical screening, and the qualitative test was carried out in different solvent extracts such as alcoholic, aqueous and chloroform extracts to detect the presence of nature of Phytoconstituents present in the formulation. The qualitative analysis for phytochemicals in IHA revealed presence of alkaloids, carbohydrates, glycoside, phenols, saponins, proteins, steroids, tannins and flavonoids. HPTLC technique is very crucial and important to detect the number of components in the extract and can provide quantitative aspects as well using the peak areas recorded in the densitogram obtained. It is the important parameter used for detecting adulteration to evaluate the quality of drugs. Major significance of HPTLC is its ability to analyse multiple samples simultaneously using small amount. Microbes cause spoilage of inappropriately processed drugs by multiplying within it, thereby causing deterioration. Once bacteria spoilage sets in there, it is difficult to stop. The consequence of microbial attack is off odour and taste and when pathogenic bacteria are involved, it could result in infection to patient. Insufficient dried formulations particularly at the processing location are prone to fungal infection, principally from the non-specific Penicillium spp., Aspergillus spp. (Fafioye et al., 2008). The natural products are prone to have the presence of microbes and the quality assurance requires to check the presence of microbes through qualitative or quantitative methods and these should be within the permissible levels set by WHO. However, the microbes which are potentially harmful for human health should never be present in a formulation like E.coli, Salmonella, etc. The heavy metals and pesticides usually accumulate in plant through soil. Consumption of such contaminated plant products may lead to various health issues and diseases like high blood pressure, change in heart rhythm or paralysis, toxicity and even death. Hence, it is recommended by WHO that every herbal products or mineral-based drugs, therefore, should be analyzed. The test reports revealed that formulation was free from pesticide residue, was found to be absent or below the limit of quantitation and, hence safe for use.

\section{Conclusion}

In the present Study, IHA, a classical Unani formulation was selected for the development of SOPs and standardization purpose and was proved effective owing to its potential benefits in skin depigmentary disorders. The present study was to formulate a standard for IHA which serves in establishing its authenticity, quality, safety and reproducibility. The standardization of IHA was very much required as there are no reports available on its quality standards. The results obtained from the study of IHA had provide limits for the quality control and to maintain the consistency of drug. Further on the basis of these generated data, the other scientific evaluation can be designed.

\section{Acknowledgement}

The authors are extremely thankful to the Director General, CCRUM, New Delhi, and also Director, NRIUMSD, Hyderabad for providing necessary research facilities to carry out the studies. Special thanks to Dr. Mohd Kashif Husain, Mr. Aslam Siddiqui and Dr. Mohammad Zakir, from NRIUMSD for their valuable support, guidance and encouragement during the study. The author also thanks to Ms. Chaitra Bandu, Mr B. Venkatesham and DRSU staff and Pharmacy Staff of NRIUMSD, Hyderabad.

\section{Conflict of interest}

The authors declare that there are no conflicts of interest in the course of conducting the research. The authors had final decision regarding the manuscript and decision to submit the findings for publication.

\section{References}

Abba, D.; Inabo, H.; Yakubu, S. and Olonitola. (2009). Contamination of herbal medicinal products marketed in Kaduna metropolis with selected pathogenic bacteria. Afr. J. Tradit. Complement. Altern. Med., 6(1):70-77. doi: 10.4314/ajtcam.v6i1.57076.

Anderson, J.M. and Baird Parker, A.C. (1975). A rapid and direct plate method for enumerating Escherichia Coli biotype I in food. J. Appl. Bacteriol., 39(2):111-117. doi: 10.1111/j.1365-2672.1975. tb00551.x. 
Aneesh, T.P.; Hisham, M.; Sekhar, M.S.; Madhu, M. and Deepa, T.V. (2009). International market scenario of traditional Indian herbal drugsIndia declining. Int. J. Green Pharm., 3(3):184-190.

Anonymous, (1996). Indian pharmacopoeia, Ministry of Health and Family Welfare, Govt. of India Delhi, India.

Anonymous, (2005). Physicochemical standards of unani formulations, Part 1, CCRUM, Ministry of Health and Family Welfare Govt. of India, Delhi.

Anonymous, (2007a). National Formulary of Unani Medicine, part II, volume I, Govt. of India, Ministry of Health and Family Welfare, Department of AYUSH, New Delhi.

Anonymous, (2007b). The Unani Pharmacopoeia of India, Part I, Department of AYUSH, Ministry of Health and Family Welfare, New Delhi.

Anonymous, (2007c). WHO guidelines for assessing quality of herbal medicines with reference to contaminants and residues. WHO Press, World Health Organization, 20 Avenue Appia, 1211 Geneva 27 , Switzerland. Available at: https://apps.who.int/iris/handle/10665/ 43510. (accessed on 17.10.2020).

Anonymous, (2010). The Unani Pharmacopoeia of India (Formulations), part II, CCRUM, Department of AYUSH, Ministry of Health and Family Welfare, New Delhi, India.

Bhushan Mishra, S. (2019). Essentials of herbal drug technology: A guide of standardization quality control, Educreation Publishing Dwarka, New Delhi, 110075.

Ekor, M. (2014). The growing use of herbal medicines: Issues relating to adverse reactions and challenges in monitoring safety. Front. Pharmacol., 4:177. doi: 10.3389/fphar.2013.00177.

Forbes, B. A.; Sahm, D.F. and Weissfeld, A. S. and Bailey, W. R. (2007). Bailey and Scott's Diagnostic Microbiology. 12 ${ }^{\text {th }}$ Edition, Elsevier, Mosby, St Louis.

Gunn, B. A.; Ohashi, D. K.; Gaydos, C. A. and Holt, E. S. (1977). Selective and enhanced recovery of group A and B streptococci from throat cultures with sheep blood agar containing sulfamethoxazole and trimethoprim. J. Clin. Microbiol., 5(6):650-655.

Hansen, W. and Yourassowsky, E. (1984). Detection of 3-glucuronidase in lactose-fermenting members of the family enterobacteriaceae and its presence in bacterial urine cultures, J. Clin. Microbiol., 20(6):1177-1179.

Hariharan, P. and Subburaju, T. (2012). Medicinal plants and its standardization: A global and industrial overview, Glob. J. Med. Plant Res., 1(1):10-13.

Hitchins, A. and Jinneman, K. (1998). Bacteriological analytical manual, Food and Drug Administration, Washington, DC.

Kamboj, V.P. (2000). Herbal medicine, Curr. Sci., 78(1):35-39. doi: 10.2307/ 24103844 .

Khan, H.M. (2009). Qarabadeen Azam, Central Council for Research in Unani Medicine, Department of AYUSH, Government of India, New Delhi.

Khan, M. (2005). Qarabadeen Azam-wa-Akmal, CCRUM, Department of AYUSH, Ministry of Health and Family Welfare, New Delhi.
Kumari, R. and Kotecha, M. (2016). A review on the standardization of herbal medicines, Int. J. Pharm. Sci. Res., 7(2):97-106.

Liu, Y. and Wu, F. (2010). Global burden of aflatoxin-induced hepatocellular carcinoma: A risk assessment, Environ. Health Perspect., 118(6): 818-824. doi: 10.1289/ehp.0901388.

Parthik, P.; Patel, N. M. and Patel, P. M. (2011). WHO Guidelines on quality control of herbal medicines, Int. J. Res. Ayur. Pharm., 2(4):1148-1154.

Rambach, A.L.A.I.N. (1990). New plate medium for facilitated differentiation of Salmonella spp. from Proteus spp. and other enteric bacteria. Appl. Environ. Microbiol., 56(1):301-303.

Rasheed, N.M.A.; Nagaiah, K.; Mehveen, A.; Rehana, A.; Waheed, M.A. and Shareef, M.A. (2010). Phytochemical evaluation and quantification of beta-sitosterol in geographical variation of Withania coagulans Dunal by HPTLC analysis. Ann. Phytomed., 1(2):14-22. doi: 10.4103/0974-8490.69115.

Rasheed, N.M.A.; Nagaiah, K. and Mehveen, A. (2012a). Phytochemical evaluation and quantification of beta-sitosterol in geographical variation of Withania coagulans Dunal by HPTLC analysis, Ann. Phytomed., 1(2):14-22.

Rasheed, N.M.A.; Nagaiah, K.; Goud, P.R. and Sharma, V.U. M. (2012b). Chemical marker compounds and their essential role in quality control of herbal medicines. Ann. Phytomed., 1(1):1-8.

Rasheed, N.M.A.; Srividya, G.S. and Nagaiah, K. (2017). HPTLC method development and quantification of curcumin content in different extracts of rhizomes of Curcuma longa L., Ann. Phytomed., 6(2):74-81. doi: 10.21276/ap.2017.6.2.6.

Sen, S. and Chakraborty, R. (2017). Revival, modernization and integration of Indian traditional herbal medicine in clinical practice: Importance, challenges and future. J. Tradit. Complement. Med., 7(2):234-244. doi: 10.1016/j.jtcme.2016.05.006

WHO, (2011). Quality control methods for herbal materials. World Health Organization, Geneva. Available at: https://apps.who.int/ iris/handle/10665/44479 (accessed on 17.10.2020)

WHO, (2014). WHO. Traditional Medicine Strategy. World Health Organization, Geneva, Switzerland. Available at: www.who.int (accessed on 17.10.2020)

WHO, (2015). WHO guidelines on good agricultural and collection practices (GACP) for medicinal plants, WHO. World Health Organization. Available at: http://www.who.int/medicines/ publications/traditional/gacp2004/en/. (Accessed on 17.10.2020)

WHO, (2018). Guidelines on good manufacturing practices for the manufacture of herbal medicines. WHO Technical Report. Available at: https:/www.who.int/traditional-complementary-integrativemedicine/publications/trs1010_annex2.pdf?ua=1. (accessed on 17.10.2020)

Zafar, M.; Rasheed, N.M.A.; Nagaiah, K. and Raju, P.V.S. (2020). Development of standard operating procedures and quality standards of Kushta Gaodanti with HPTLC fingerprinting and hyphenated techniques. Ann. Phytomed., 9(1):66-77. http:// dx.doi.org/10.21276/ap.2020.9.1.8

Citation Aaisha Ansari, Mohammed Abdul Rasheed Naikodi, Uzma Viquar, Javed Inam Siddiqui and Munawwar Husain Kazmi (2020). Development of standard operating procedures, phytochemical screening with HPTLC fingerprint of a polyherbal formulation. Ann. Phytomed., 9(2):142-154. http://dx.doi.org/10.21276/ap.2020.9.2.12 